\title{
Explaining the Cross-Sectional Patterns of UK Expected Stock Returns: The Effect of Intangibles
}

\author{
Walid Saleh ${ }^{1}$ \\ ${ }^{1}$ Department of Business, Arab Open University- Jordan Branch, Amman, Jordan \\ Correspondence: Walid Saleh, Associate Professor of Corporate Finance, Department of Business, Arab Open \\ University- Jordan Branch, P.O.Box 1339, Amman 11953, Jordan. Tel: 962-6-563-0630. E-mail: \\ w_saleh@aou.edu.jo,wsaleh99@yahoo.com \\ Received: February 14, 2014 \\ Accepted: March 6, $2014 \quad$ Online Published: April 6, 2014 \\ doi:10.5430/ijfr.v5n2p160 \\ URL: http://dx.doi.org/10.5430/ijfr.v5n2p160
}

\begin{abstract}
Previous UK studies of value-glamour investing strategies confirm the existence of anomalous returns. That is, most of the studies reveal that value stocks outperform glamour stocks. Several explanations were introduced for such phenomena. The rational approach argues for the risk explanation whereas, the irrational approach asserts on the miss-pricing explanation.

This paper investigates the effect of intangibles in explaining the variation in stock returns. Thus, the paper developed an "intangibles-gap" for each stock listed during the period of the study. Then, the paper conducts a portfolio analysis approach to test the effect of intangibles in explaining the cross-sectional stock returns. The results show that the miss-pricing explanation is prevailed in the first two years of portfolio formulation. However, the market reacts to this by adjusting stock prices; thus, the strategy of holding long position of undervalued stocks against short position of overvalued stocks becomes unattractive in the third to fifth-year.
\end{abstract}

Keywords: value-glamour strategy, Fama-French Model, stock returns, intangible assets

\section{Introduction}

A considerable body of research has been directed to explain the patterns of stock returns. Several studies have confirmed that value measures such as the book-to-market ratio, the market value of equity, and earnings-price ratio, amongst others can predict the cross-sectional patterns of stock returns (e.g. Fama and French, 1992, and 1996; Jaffe, Keim, and Westerfield, 1989; Lakonishok, Shleifer, and Vishny, 1994; Strong and Xu, 1997; Gregory, Harris, and Michou, 2003; Dissanaike, 1997, 1999; and 2002; Levis and Liodakis, 1999, Kubota, Sudu, and Takehara, 2002; and Chan, Hamao, and Lakonishok, 1991).

Lakonishok, Shleifer, and Vishny (1994), Fama and French (1993 and 1998), Cai (1997), Gregory, Harris, and Michou (2001), Strong and Xu (1997), and Dissanaike (2002) demonstrate that high book-to-market, earnings-to-price, or cash-flow-to-price stocks generate higher average returns than low stocks.

Damodarn (2012) addresses the question who is a value investor? He argues that there are different forms of value investing. Firstly, "passive value investing", in which value investors look at stocks that meet certain characteristics (e.g. undervalued stocks; low multiples of earnings and book value). Secondly, "contrarian investing" in which value investors buy stock when it is down. Finally, "activist value investing", in which value investors take large positions in undervalued and poorly managed companies and making money from turning them around. Hang and Zhou (2013) propose a trend factor to explain the cross-sectional stock returns. They argue that the trend factor explains better than the momentum factor. Bali and Engle (2012) investigate the performance of conditional CAPM in explaining the superiority of value stocks. They show that "the dynamic conditional covariances of book-to-market portfolios with default spread, dividend yield, and unemployment rate are significant predictors of future returns".

Asness and Frazzini (2011) critic the standard method of constructing value portfolios and the standard method of calculating book to price ratios. They show that using more up to date price (e.g. updating value measures and portfolios monthly instead of annually) is superior to the standard methods used by Fama and French (1993).

Fernandez (2013) analyzes the relationship between share prices and their book values in several companies in different countries. Also, the author analyzes the effect of price to earnings ratio on this relationship. He concludes 
that the book to market ratio is closely related with the price to earnings ratio and the return on equity. Further, his results assert that the price to earnings ratio depends on several factors such as interest rate (an external factor), company's risk, company's growth, and its return on investments (internal facors).

Some researchers (e.g. Lakonishok, Shliefer and Vishny, 1994, amongst others) argue in favour of irrational investor behaviour when explaining the superiority of value stocks. They argue that value stocks outperform glamour stocks because the market undervalues value stocks and overvalues glamour stocks. That is, investors assume that stocks that have done very well in the recent past will continue to do so, thus, they overbuy them. Consequently, these stocks, glamour stocks, become overpriced. Likewise, investors assume that stocks that have performed poorly in the recent past will continue to do so, thus, they oversell them. As a result, these out-of-favour stocks become under-priced, value stocks.

In contrast to the irrational investor explanation, other researchers (e.g. Fama and French, 1993) argue in favour of rational investment behaviour in explaining the value premium. The argument is that value stocks outperform glamour stocks because value stocks are fundamentally riskier in some aspects than glamour stocks and therefore in supporting efficient market hypothesis.

Lo and Mackinlay (1990) and Kothari, Shanken, and Sloan, (1995) suggest different interpretation of the superiority of value stocks. They argue for bias induced by research design, such as survivorship bias and data "snooping" in the selection of the sample. Conrad and Kaul (1993) argue that such superiority can be explained by the bid-ask spread and infrequent trading.

This paper seeks to explore the superiority of the value investment strategies documented in prior research by using different value measures. In particular, the paper aims to build on the modified version of the Ohlson model proposed by Gregory, Saleh and Tucker (2005), hereafter referred to as GST (2005). Thus, this paper will provide additional evidence regarding whether the abnormal returns found from "value" versus "glamour" investing strategies are largely associated with a naive over-extrapolation of past earnings alone or whether they also account for the intangible effects.

To summarise the key results, the paper shows that undervalued stocks outperform overvalued stocks in the first two years of portfolio formulation. However, it seems that the market reacts to this by adjusting stock prices. Therefore, such trading strategy becomes unattractive in the third, forth, and fifth-year of portfolio formulation. Furthermore, the paper shows that the Fama-French three factor model does not explain the variation in stock return for the hedge portfolio, whereas it explains small parts of individual portfolio returns (up to 35\%). The author believes that including the intangibles effect in explaining the cross-sectional returns will open new rooms for extra research in the field.

The remainder of this paper is divided into the following sections. Section 2 provides research hypothesis. Section 3 describes the methodology employed in this study. Section 4 discusses the empirical results. Finally, section 5 summarises and concludes

\section{Research Hypothesis}

Prior studies have confirmed the significant role of intangible assets in the firm's future performance (e.g. Lambert, 2001; Bugeja et al., 2006; Sahut et al. 2011, amongst others). For instance, Wyatt (2008) documented the value relevance of intangible assets. Furthermore, David and Lev (1998) found that cumulative intangible asset is associated with stock prices. Also, they reported that intangibles capitalization data (e.g. R\&D) are associated with subsequent reported earnings. The above results motivate us to investigate the effect of intangible assets in explaining the patterns of stock return.

Notice that the value of all net assets (tangible and intangible assets) is reflected in the firm's market value. Brigham (1992) showed that the firm's market value takes into account the potential growth into valuation. Moreover, notice that since some intangible assets are not recognized in the financial statements under IFRS, book value of equity will be lower than the fair value of that asset. This suggests that intangible assets will increase market value of the firm.

Proponents of efficient markets argue that value stocks outperform glamour stocks due to the increased risk of value stocks. Alternatively, if we accept that investors' irrationality may be the cause of the book-to-market effect, we must also accept that the degree of irrationality is a pertinent issue. An over-extrapolation of returns clearly gives rise to profitable investment opportunities. This paper argues that if we take into accounts the intangibles effect, then undervalued securities (that is, investors undervalued the effect of intangible assets of those firms) will outperform overvalued securities (that is, investors overvalued the effect of intangible assets of those firms). Thus, this paper seeks to contribute in this field of research by investigating the effect of intangibles in explaining variation in stock 
returns.

\section{Research Methodology}

\subsection{The Intangibles Effect}

The paper uses a straightforward approach to estimate the intangible effects as follows. Firstly, the paper assumes that market value of equity (stock price multiplied by number of shares outstanding) equates to the total paid for all of the acquired firm's assets; including all payments and liabilities assumed. Secondly, the paper estimates the magnitude of intangible assets (hereafter, referred as "intangibles-gap") by subtracting from the market value of equity the estimated fair value of assets (current assets and tangible assets). To do so, the paper adjusts the recorded values of assets to fair values as follows:

This paper employs current cost accounting approach to estimate the fair value of equity. To do so, the paper uses the real version of the Ohlson (1995) model, proposed by GST (2005) (Note 1). The dividend discount model relies on one proposition: asset prices represent the present value of all expected dividends, that is (Note 2):

$$
P_{t}=\sum_{J=1}^{\infty} R^{-J} \cdot E\left(d_{t+i}\right)
$$

Where $P t$ is the market price of equity at date $t, d t$ is the dividends received at the end of period $t, R$ is unity plus the discounted rate $r$, and $E t$ is the expectation operator based on the information set at date $t$.

To derive the residual income model (Note 3) from the present value of all expected dividends, two additional assumptions are made (e.g Ohlson, 1995, Peasnell, 1982 and Edwards and Bell, 1961). First, the book value of equity follows a "clean surplus" relation (Note 4$)$ that only earnings $(X t)$ and net dividends modify book equity. That is,

$$
b_{t}=b_{t-1}+x_{t}-d_{t}
$$

Where $b t$ represents book value of equity at date $t, x_{t}$ represents earnings for period $t$ and $d t$ refers to net dividends distributed to shareholders at time $t$. Second, the book value of equity grows at a rate less than $R$ (Lo and Lys, 2000), that is:

$$
R^{-J} \cdot E\left(b_{t+J}\right) \stackrel{J \rightarrow \infty}{\longrightarrow} 0
$$

Combining the two assumptions gives the residual income valuation model expression (Note 5):

$$
P_{t}=b_{t}+\sum_{J=1}^{\infty}(R)^{-J} \cdot E\left(x_{t+j}^{a}\right)
$$

Where $x_{t}^{a}=x_{t}-r \cdot b_{t-1}$ is the abnormal earnings (Note 6). The valuation function in the residual income model is consistent with the idea that a company is expected to live forever. For valuation purposes, a finite horizon point in time is often introduced in this function (Note 7).GST define an inflation index (base year 0 ) for year $t$ as:

$$
I_{t}=\prod_{s=0}^{t}\left(1+i_{s}\right)
$$

and a real (in year 0 price levels) equivalent of the dividend series given by $d_{t}^{\prime}$ where the real dividend is defined as:

$$
d_{t}^{\prime}=d_{t} / I_{t}
$$

Then, they assume that there is a constant real cost of capital, $r^{\prime}$, so that a real terms valuation function can be defined as: 


$$
R_{t}^{-j}=\frac{R_{t}^{-j}}{I_{t}}
$$

Thus, the residual income valuation model can now be expressed in real terms as:

$$
P_{t}=\sum_{J=1}^{\infty} R^{\prime-J} \cdot E\left(d_{t+i}^{\prime}\right)
$$

Further they define $A_{t}$ as the book value of assets at time $t, D_{t}$ as the book value of debt at time $t$, so that $B_{t}=A_{t}-D_{t}, a_{t}$ as the investment in tangible and intangible net assets, and $m_{t}$ as the investment in monetary net assets (for simplicity we assume that the working capital cycle is zero days (Note 8)) during year $t$, so that $A_{t}=A_{t-1} /\left(1+\delta_{t}\right)+a_{t}+m_{t}$, where $\delta_{t}$ is the rate of depreciation at the end of year $t$ (Note 9$)$.

Cash flow, $c_{t}$, is defined so that $x_{t}=c_{t}-\left[1-\frac{1}{\left(1+\delta_{t}\right)}\right] A_{t-1}-D_{t}+D_{t-1}$. The accounting identity implies that $d_{t}=c_{t}-a_{t}-m_{t}$, hence:

$$
\begin{aligned}
& b_{t}=A_{t-1}-\left(1-\frac{1}{1+\delta_{t}}\right) \cdot A_{t-1}-D_{t}+D_{t-1}+a_{t}+m_{t} \\
& =\frac{b_{t-1}}{1+\delta_{t}}+a_{t}+m_{t}-D_{t}+D_{t-1}
\end{aligned}
$$

Next, they define an approximation of the current replacement book value of assets, $b_{t}^{\prime}$ and a current replacement cost depreciation charge. They assume that asset prices increase in line with the general rate of inflation and that the rate of technological innovation is given by $\theta_{t}$. Assuming the firm commenced business in year zero, as Lindenberg and Ross (1981) show the recursive relation of replacement cost of assets will be given by:

$$
b_{t}^{\prime}-m_{t}=\left(b_{t-1}^{\prime}-m_{t-1}\right)\left(\frac{\left[1+i_{t}\right]}{\left[1+\delta_{t}\right]\left[1+\theta_{t}\right]}\right)+a_{t}
$$

Continuing the recursion they have:

$$
b_{t}^{\prime}-m_{t}=\sum_{\tau=0}^{t} \prod_{s=\tau}^{t}\left(\frac{\left[1+i_{s}\right]}{\left[1+\delta_{s}\right]\left[1+\theta_{s}\right]}\right) a_{\tau}
$$

Note they assume that the rate of depreciation on current cost asset values is identical to the rate of depreciation on historical book values. The historical book value of the fixed assets is simply:

$$
b_{t}-m_{t}=\sum_{\tau=0}^{t} \prod_{s=\tau}^{t}\left(\frac{1}{1+\delta_{s}}\right) a_{\tau}
$$

So that difference between historical book values and nominal book values, or the cumulative holding gain, is defined as:

$$
b_{t}^{\prime}-b_{t}=\sum_{\tau=0}^{t} \coprod_{s=\tau}^{t}\left(\frac{1}{1+\delta_{s}}\right)\left[\frac{\prod_{s=\tau}^{t}\left(1+i_{s}\right)}{\prod_{s=\tau}^{t}\left(1+\theta_{s}\right)}--1\right] a_{\tau}
$$

Real earnings expressed in end year $t$ price levels can then be defined as (Note 11):

$$
x_{t}^{r t}=x_{t}-h_{t}=b_{t}^{\prime}-\left(1+i_{t}\right) b^{\prime}{ }_{t-1}+d_{t}
$$

So real abnormal earnings in year $t$ can now be defined as: 


$$
x_{t}^{a r t}=b_{t}^{\prime}-\left(1+r^{\prime}\right)\left(1+i_{t}\right) b_{t-1}^{\prime}+d_{t}
$$

Making the usual assumption for residual income and dividend discount models, that the present value of the book assets in year $N$ will be approximately zero, enables the final term to be dropped, which then leaves:

$$
P_{t}=b_{t}^{\prime}+\sum_{\tau}^{\infty} \frac{x_{t+\tau}^{a r t}}{(1+r)^{\tau}}
$$

Thus, GST follow the spirit of Ohlson but assume that the real abnormal earnings follow an autoregressive process of the following type:

$$
\begin{aligned}
& x_{t+1}^{a r t}=\omega x_{t}^{a r t}+v_{t}+\varepsilon_{1, t+1} \\
& v_{t+1}=\gamma v_{t}+\varepsilon_{2, t+1}
\end{aligned}
$$

To estimates the other information variable, the paper applies Capstaff, Paudyal, and Rees (1995) framework to estimate earnings forecast error. The persistence parameter of abnormal earnings and the persistence parameter of the other information variable are estimated over the period 1995-2012 as follows:

$$
\begin{gathered}
x_{t+1}^{a}=\omega_{0}+\omega_{1} x_{t}^{a}+e_{t+1} \\
v_{t+1}=\gamma_{0}+\gamma_{1} v_{t}+e_{t+1}
\end{gathered}
$$

Based on the above, the main model specification can be described as follows:

$$
P_{t}=b_{t}+\alpha_{1} x_{t}^{a}+\alpha_{2} v_{t}
$$

This specification includes estimated replacement book value of equity, current abnormal earnings, and value-relevant information from non-accounting source. Also, notice that the paper tests for another model specification that only includes the estimated replacement book value of equity. However, the paper only reports the results of the main specification since there is no significant difference in the results.

Thus, the ratio of "intangibles-gap" can be represented as follows:

Intangibles-gap $=($ Market value of equity - Fair value of equity $) /$ market value of equity six

months after the fiscal year end

\subsection{The Portfolio Formation Procedure}

This paper conducts a portfolio analysis approach to investigate the effect of intangibles in explaining the variation in stock returns. Based on equation (20) above, the paper uses the "intangibles-gap" ratio values. For each year, then, stocks are sorted into deciles based on "intangibles-gap" ratio values. Lower deciles consist of stocks that are undervalued (intangibles-gap is less than one) and are likely to experience higher future stock returns. Higher deciles consist of stocks that are overvalued (intangibles-gap is greater than one) and are expected to generate lower future stock returns.

We begin portfolio formation on the first of September every year because more than two thirds of the firms listed on the London Stock Exchange have their fiscal year end in December and March. To be included in the sample, firms must have data on the "intangibles-gap" ratio recorded between the end of April of year $t-1$ and the first of May of year $t$. The proceeds from a stock that de-lists during the holding period are distributed among other stocks in the portfolio according to their value-weight. The paper allows for at least a four-month lag between the measurement of accounting and returns data to ensure that accounting data are available at the date of formation. For each portfolio, the paper computes returns for: (1) each of the following five years, R1 to R5; (2) the average annual return over the five-year period (AR); and, (3) the average cumulative five-year return with annual compounding.

\subsection{Risk Adjusted Returns}

In order to explore the effect of intangibles to predict future long-run returns of up to five years, the paper conducts a portfolio analysis approach. The paper employs the Fama and French (1993) three-factor model to explain the difference in returns between low and high "intangibles-gap" stocks. The model is:

$$
R_{i t}-R_{f t}=a_{i}+\beta_{i}\left(R_{m t}-R_{f t}\right)+s_{i} S M B_{t}+h_{i} H M L_{t}+e_{\mathrm{it}}
$$


Where:

$R i=$ the monthly portfolio value-weighted returns., $R_{m}=$ the monthly return of the FTSE All Share Total Return Index, $R_{f}=$ the monthly 3-month Treasury bill rate at the beginning of the month

\section{Empirical Results}

\subsection{Analysis of Raw Returns}

Table 1 reports value-weighted returns for portfolios formed based on values of the "intangibles-gap" ratio. The average return for the P1 to P10 portfolios over the five-year period is 0.172 and the average cumulative five-year return for $\mathrm{P} 1$ to $\mathrm{P} 10$ portfolios is 0.642 . Also, the results show that the average return for the hedge portfolio (P1-P10) is 0.008 and the average cumulative five-year return for this portfolio is 0.045 . The one-year to five-year returns (R1 to R5) for the hedge portfolio are $0.105,0.035,-0.084,-0.010$, and -0.034 , respectively. These results suggest that undervalued stocks (e.g. P1 portfolio) outperform overvalued stocks (e.g. P10 portfolio) in the first and second year.

Table 1. Value weighted returns for portfolios based on the "intangibles-gap" ratio

\begin{tabular}{cccccc}
\hline & P1 & P2 & P3 & P4 & P5 \\
\hline R1 & 0.301 & 0.279 & 0.223 & 0.059 & 0.186 \\
R2 & 0.235 & 0.246 & 0.167 & 0.107 & 0.105 \\
R3 & 0.212 & 0.172 & 0.192 & 0.098 & 0.104 \\
R4 & 0.132 & 0.244 & 0.335 & 0.127 & 0.162 \\
R5 & 0.161 & 0.105 & 0.332 & 0.122 & 0.154 \\
AR & 0.208 & 0.209 & 0.250 & 0.103 & 0.142 \\
CR5 & 0.866 & 0.751 & 0.861 & 0.376 & 0.497 \\
\hline R1 & P7 & P8 & P9 & P10 & P1-P10 \\
R2 & 0.170 & 0.124 & 0.191 & 0.196 & 0.105 \\
R3 & 0.142 & 0.132 & 0.126 & 0.201 & 0.035 \\
R4 & 0.212 & 0.152 & 0.207 & 0.220 & -0.084 \\
R5 & 0.263 & 0.149 & 0.129 & 0.139 & -0.010 \\
AR & 0.169 & 0.123 & 0.083 & 0.244 & -0.034 \\
CR5 & 0.191 & 0.136 & 0.147 & 0.200 & 0.008 \\
\hline & 0.660 & 0.476 & 0.607 & 0.821 & 0.045 \\
\hline & & & Average & 0.189 & 0.158 \\
\end{tabular}

Note: Table 1 values represent mean one- to five-year buy and hold return for portfolios formed on September each year, based on the "intangibles-gap" ratio. The sample period is 1995-2012. AR is the average return for R1-R5. CR5 is the five-year cumulative return. P1-P10 represents the difference between portfolio 1 and portfolio 10 .

However, it seems that the market realizes this superiority of such trading strategy and thus, adjusts stock prices starting from year three; notice that such trading strategy (long position on P1 stocks and short position on P10 stocks) becomes unattractive in the third, forth, and fifth years; the returns are $-0.084,-.010$, and -.0034 , respectively. The above results confirm that the market reacts to the undervalued and overvalued stocks (that is, investors discover that they undervalued or overvalued the effect of intangible assets and, thus, react by adjusting their positions in these stocks) by adjusting their prices.

\subsection{Risk-Return Analysis}

The paper starts by testing whether the Fama-French three factor model can explain portfolio returns in each of our deciles and differences between undervalued and overvalued stocks (the returns in our P1-P10 portfolios). Table 2 presents Fama-French three factor model parameters with decile returns or P1-P10 returns as the dependent variable. Here, the paper uses monthly returns for portfolios based on the "intangibles-gap" ratio over a five-year horizon. The intercept is typically not close to zero with a few exceptions for P2 and P4 portfolios. This means that the loading of the intercept factor is significant at 5 percent level. The estimated loading of the market factor is highly significant 
for individual portfolios, but not for the hedge portfolio (P1-P10).

The loading of book-to-market factor is not significant for the extreme portfolios (P1 and P10). However, the loading of the size factor is positive and significant for these extreme portfolios. The loading of the three-factor model parameters for the hedge portfolio (P1-P10) is not significant except for the size factor (1.92); which is marginally significant at 10 percent level. The adjusted R-square for the individual portfolios ranges from 0.04 to 0.35 , whilst it is 0.01 for the hedge portfolio. These results suggest that the Fama-French three-factor model does not explain the variation in stock returns for the hedge portfolio (undervalued intangible stocks versus overvalued intangible stocks). This opens a new room for extra research in the field to shed further light on the effect of intangibles in explaining cross-sectional stock returns.

Table 2. Three-factor time series regressions for monthly excess returns for portfolios based on the "intangibles-gab" ratio

\begin{tabular}{|c|c|c|c|c|c|}
\hline & P1 & P2 & P3 & P4 & P5 \\
\hline $\mathrm{a}$ & 0.0166 & 0.116 & 0.012 & 0.001 & 0.0133 \\
\hline ta) & 2.45 & 1.17 & 3.06 & 0.391 & 3.34 \\
\hline $\mathrm{b}$ & 0.445 & -1.32 & 0.487 & 0.528 & 0.317 \\
\hline t(b) & 2.54 & -0.51 & 4.68 & 6.34 & 3.05 \\
\hline $\mathrm{s}$ & 0.631 & -4.60 & 0.601 & 0.340 & 0.369 \\
\hline $\mathrm{t}(\mathrm{s})$ & 3.67 & -1.82 & 5.94 & 4.17 & 3.62 \\
\hline $\mathrm{h}$ & -0.046 & 3.78 & -0.21 & -0.07 & -0.225 \\
\hline $\mathrm{t}(\mathrm{h})$ & -0.35 & 1.95 & -2.64 & -1.10 & -2.89 \\
\hline \multirow[t]{2}{*}{$\mathrm{R}^{2}$} & 0.12 & 0.04 & 0.35 & 0.32 & 0.20 \\
\hline & P7 & P8 & P9 & P10 & P1-P10 \\
\hline $\mathrm{a}$ & 0.012 & 0.007 & 0.012 & 0.013 & 0.0036 \\
\hline ta) & 3.45 & 2.86 & 4.54 & 3.39 & 0.44 \\
\hline $\mathrm{b}$ & 0.343 & 0.352 & 0.339 & 0.368 & 0.077 \\
\hline $\mathrm{t}(\mathrm{b})$ & 3.81 & 5.18 & 5.00 & 3.69 & 0.414 \\
\hline $\mathrm{s}$ & 0.095 & 0.227 & 0.208 & 0.284 & 0.347 \\
\hline $\mathrm{t}(\mathrm{s})$ & 1.07 & 3.42 & 3.12 & 2.91 & 1.92 \\
\hline $\mathrm{h}$ & 0.006 & 0.102 & 0.111 & 0.047 & -0.093 \\
\hline $\mathrm{t}(\mathrm{h})$ & 0.089 & 2.01 & 2.17 & 0.631 & -0.676 \\
\hline \multirow[t]{11}{*}{$\mathrm{R}^{2}$} & 0.09 & 0.22 & 0.21 & 0.13 & 0.01 \\
\hline & & & & Average & \\
\hline & $\mathrm{a}$ & & & 0.0214 & \\
\hline & $\mathrm{t}(\mathrm{a})$ & & & 2.87 & \\
\hline & $\mathrm{b}$ & & & 0.219 & \\
\hline & $\mathrm{t}(\mathrm{b})$ & & & 3.84 & \\
\hline & $\mathrm{s}$ & & & -0.178 & \\
\hline & $\mathrm{t}(\mathrm{s})$ & & & 2.71 & \\
\hline & $\mathrm{h}$ & & & 0.349 & \\
\hline & $\mathrm{t}(\mathrm{h})$ & & & -0.028 & \\
\hline & $\mathrm{R}^{2}$ & & & 0.182 & \\
\hline
\end{tabular}

Notes: $\mathrm{R}_{\mathrm{it}}-\mathrm{R}_{\mathrm{ft}}=\mathrm{a}_{\mathrm{i}}+\beta_{\mathrm{i}}\left(\mathrm{R}_{\mathrm{m}}-\mathrm{R}_{\mathrm{ft}}\right)+\mathrm{s}_{\mathrm{i}} \mathrm{SMB}+\mathrm{h}_{\mathrm{i}} \mathrm{HML}+\mathrm{e}_{\mathrm{it}}$,

Here, $R_{i t}$ is the monthly portfolio return, $R_{f t}$ is the monthly Treasury bill rates at the beginning of the month, and $R_{m t}$ is the monthly returns of the FTSE All Share Total Return Index. $t()$ are the t-statistics with standard errors calculated using White (1980) corrections. $\mathrm{R}^{2}$ is adjusted for degrees of freedom. SMB (small minus big) is the difference, each month, between the average of the returns on the three small-stock portfolios $(\mathrm{S} / \mathrm{L}, \mathrm{S} / \mathrm{M}$, and $\mathrm{S} / \mathrm{H})$ and the average of the returns on the three big- stock portfolios $(\mathrm{B} / \mathrm{L}, \mathrm{B} / \mathrm{M}$, and $\mathrm{B} / \mathrm{H})$. $\mathrm{HML}$ is the difference, each month, between the average of the returns on the two high-book-to-market portfolios $(\mathrm{S} / \mathrm{H}$ and $\mathrm{B} / \mathrm{H})$ and the average of the returns on the two low-book-to-market portfolios ( $\mathrm{S} / \mathrm{L}$ and $\mathrm{B} / \mathrm{L}$ ). Hedge return (P1-P10) represents the difference between portfolio 1 and portfolio 10. The sample period is 1995-2012.

\section{Summary and Conclusions}

The analysis presented has investigated whether intangibles accrue to a value investment strategy based upon the inflation-adjusted Ohlson model of Gregory, Saleh and Tucker (2005). In so doing, the paper also explores whether 
the "intangible assets gap" can provide any insights into the miss-pricing versus the rational risk pricing debate.

The evidence here suggests that the miss-pricing explanation holds in the first two years, but it disappears in the long term (three to five years). Moreover, the paper finds that a three factor model cannot explain the returns to an investment strategy based on a model which allows for the intangible effects.

\section{References}

Aboody, D., Mary E. Barth, \& Ron Kasznik. (1999). Revaluations of Fixed Assets and Future Firm Performance: Evidence from the UK. Journal of Accounting and Economics, 26, 149-178.

Asness, G. S., \& Frazzini, A. (2011). The Devil in HML's Dtails. Working paper, AQR Capital Management.

Bali, T. G., \& Engle, R. F. (2013). The conditional CAPM explains the value premium. Working paper, Georgetown McDonough School of Business Research Paper.

Brigham, E. F. (1992). Fundamentals of Financial Management. Fort Worth. Dryden Press.

Bugeja, M., \& Gallery, N. (2006). Is older goodwill relevant? Accounting and Finance, 46(4), 519-535.

Bulkley, G., \& Harris, R. D. F. (1997). Irrational analysts expectations as a cause of excess volatility in stock prices. Economic Journal, 107, 359-371. http://dx.doi.org/10.1111/j.0013-0133.1997.163.x

Cai, J. (1997). Glamour and value strategies on the Tokyo Stock Exchange. Journal of Business Finance and Accounting, 24(9\&10), 1291-1310. http://dx.doi.org/10.1111/1468-5957.00163

Capstaff, J., K. Paudyal, \& W. Rees. (1995). The Accuracy and Rationality of Earnings Forecasts By UK Analysts. Journal of Business and Accounting, 22(1), 67-85. http://dx.doi.org/10.1111/j.1468-5957.1995.tb00672.x

Chan, L., Hamao, Y., \& Lakonishok, J. (1991). Fundamentals and stock returns in Japan. Journal of Finance, 46, 1739-1764. http://dx.doi.org/10.1111/j.1540-6261.1991.tb04642.x

Conrad, J., \& Kaul, G. (1993). Long-term market overreaction or biases in computed returns?. Journal of Finance, 48, 39-63. http://dx.doi.org/10.1111/j.1540-6261.1993.tb04701.x

Damodarn, A. (2012). Value investing: investing for growth ups? Working Paper, Newyork University.

Daniel, K., \& Titman, D. (1997). Evidence on the characteristics of cross-sectional variation in stock returns. Journal of Finance, 52, 1-33. http://dx.doi.org/10.1111/j.1540-6261.1997.tb03806.x

David, A., \& Lev, B. (1998). The Value Relevance of Intangibles: The Case of Software Capitalization. Journal of Accounting Research, 36, 161-191.

DeBondt, W., \& Thaler, R. H. (1985). Does the stock market overact?. Journal of Finance, 40, 793-805. http://dx.doi.org/10.1111/j.1540-6261.1985.tb05004.x

DeBondt, W., \& Thaler, R. H. (1987). Further investigation on investor overreactionand stock seasonality. Journal of Finance, 42, 557-581. http://dx.doi.org/10.1111/j.1540-6261.1987.tb04569.x

Dissanaike, G. (1997). Do stock market investors overreact?. Journal of BusinessFinance and Accounting, 24, 27-49. http://dx.doi.org/10.1111/1468-5957.00093

Dissanaike, G. (1999). Long-term stock price reversals in the UK: Evidence from regression test. British Accounting Review, 31, 373-385. http://dx.doi.org/10.1006/bare.1999.0115

Dissanaike, G. (2002). Does the size effect explain the UK winner-loser effect? Journal of Business Finance and Accounting, 29(1\&2), 139-154. http://dx.doi.org/10.1111/1468-5957.00427

Edwards, E., \& Bell, P. (1961). The Theory and Measurement of Business Income. University of California Press, Berkeley, CA.

Fama, E., \& French, K. (1992). The cross-section of expected stock returns. Journal of Finance, 46, 427-466. http://dx.doi.org/10.1111/j.1540-6261.1992.tb04398.x

Fama, E., \& French, K. (1993). Common risk factors in the returns on stocks and bonds. Journal of Financial Economics, 33, 3-56. http://dx.doi.org/10.1016/0304-405X(93)90023-5

Fama, E., \& French, K. (1995). Size and book-to-market factors in earnings and returns. Journal of Finance, 50, 131-155. http://dx.doi.org/10.1111/j.1540-6261.1995.tb05169.x

Fama, E., \& French, K. (1996). Multifactor explanations of assets pricing anomalies. Journal of Finance, 51, 55-84. http://dx.doi.org/10.1111/j.1540-6261.1996.tb05202.x 
Fama, E., \& French, K. (1998). Value versus growth: the international evidence. Journal of Finance, 53, 1975-1998. http://dx.doi.org/10.1111/0022-1082.00080

Fernandez, P. (2013). Price to earnings ratio, value to book ratio and growth. Working Paper. University of Navarra-IESE Business School.

Gregory, A., Harris, R. D. F., \& Michou, M. (2001). An analysis of contrarian investment strategies in the UK. Journal of Business Finance and Accounting, 28, 1-36. http://dx.doi.org/10.1111/1468-5957.00412

Gregory, A., Harris, R. D. F., \& Michou, M. (2003). Contrarian investment and macroeconomic risk. Journal of Business Finance and Accounting, 30(1\&2), 213-255. http://dx.doi.org/10.1111/1468-5957.00004

Gregory, A., Saleh, W., \& Tucker, J. (2005). A UK test of a real Ohlson model. Journal of Business Finance and Accounting, 32(3\&4), 487-534. http://dx.doi.org/10.1111/j.0306-686X.2005.00602.x

Han, Y., \& Zhou, G. (2013). Trend factor: A new determinant of cross-section stock returns. Working Paper, University of Colorado and Washington University.

Jaffe, J. F., Keim, D. B., \& Westerfield, R. (1989). Earnings yields, market values, and stocks returns. Journal of Finance, 50, 135-147. http://dx.doi.org/10.1111/j.1540-6261.1989.tb02408.x

Kothari, S. P., Shanken, J., \& Sloan, R. G. (1995). Another look at the cross-section of expected returns. Journal of Finance, 50, 185-224. http://dx.doi.org/10.1111/j.1540-6261.1995.tb05171.x

Kubota, K., Sudu, K., \& Takehara, H. (2002). Common risk factors vs. Mispricing factor of Tokyo Stock Exchange firms: Inquiries into the fundamental price derived from analysts' earnings forecasts. Working Paper, Musashi University, Kobe University and the University of Tsukuba.

Lakonishok, J., Shleifer, A., \& Vishny, R.W. (1994). Contrarian investment, expectation, and risk. Journal of Finance, 49, 1541-1578. http://dx.doi.org/10.1111/j.1540-6261.1994.tb04772.x

Lambert, R.A. (2001). Contracting Theory and Accounting. Journal of Accounting and Economics, (32), 3-87.

LaPorta R. (1996). Expectations and the cross section of expected returns. Journal of Finance, 51, 1715-1742. http://dx.doi.org/10.1111/j.1540-6261.1996.tb05223.x

Levis, M., \& Liodakis, M. (1999). The profitability of style rotation strategies in the United Kingdom. Journal of Portfolio Management, (Fall), 73-86. http://dx.doi.org/10.3905/jpm.1999.319770

Lindenberg, E.B., \& S.A. Ross. (1981). Tobin's Q Ratio and Industrial Organization. Journal of Business, 54(1), 1-32. http://dx.doi.org/10.1086/296120

Lo, A. W., \& A. C. Mackinlay. (1990). Data-Snooping Biases In Test of Financial Asset Pricing Models. Review of Financial Studies, 3, 431-467.

Lo, King, \& Thomas, Lys. (2000). The Ohlson Model: Contribution to Valuation Theory, Limitation, and Empirical Applications. Working Paper, University of British Columbia.

McCare, M., \& Nilsson, H. (2001). The Explanatory and Predictive Power of Different Specifications of the Ohlson (1995) Valuation Models. The European Accounting Review, 10(2), 315-341.

O'Hanlon, J. (2005). Discussion of: A UK test of a real Ohlson model. Journal of Business Finance and Accounting, 32(3\&4), 535-548. http://dx.doi.org/10.1111/j.0306-686X.2005.00603.x

O’Hanlon, J., \& Peasnell, K. V. (2004). Residual income valuation: are inflation adjustments necessary? Review of Accounting Studies, 9(4), 375-398.

Ohlson, J. A. (1995). Earnings, book values, and dividends in equity valuation. Contemporary Accounting Research, 11(2), 661-678. http://dx.doi.org/10.1111/j.1911-3846.1995.tb00461.x

Peasnell, K.V. (1982). Some formal connections between economic values and yields and accounting numbers. Journal of Business Finance and Accounting, 9(3), 361-81. http://dx.doi.org/10.1111/j.1468-5957.1982.tb01001.x

Penman, S., \& T. Sougiannis. (1998). A comparison of Dividend, Cash Flow, and Earnings Approaches to Equity Valuation. Contemporary Accounting Research, 5(3), 343-383.

Sahut, J., M., Boulerne, S., \& Teulon, F. (2011). Do IFRS provide better information about intangibles in Europe? Review of Accounting and Finance, 10(3), 267-290. 
Samuels, J.M., R.E. Brayshaw, \& J.M. Craner. (1995). Financial Statement Analysis in Europe. Chapman \& Hall, London.

Strong, N., \& Xu, G. (1997). Explaining the cross section of UK expected returns. British Accounting Review, 29, 1-23. http://dx.doi.org/10.1006/bare.1996.0030

Walker, M. (1997). Clean surplus accounting models and market-based accounting research: a review. Journal of Accounting and Business Research, 27(4), 341-55. http://dx.doi.org/10.1080/00014788.1997.9729559

White, H. (1980). A heteroskedasticity-consistent covariance matrix estimator and a direct test for heteroskedasticity. Econometrica, 48, 817-838. http://dx.doi.org/10.2307/1912934

Wyatt, A. (2008). What Financial and Non-Financial Information on Intangibles is value relevant? A Review of the evidence. Accounting and Business Research, 38(3), 217-256.

\section{Notes}

Note 1. This model deals with a particular aspect of "dirty surplus" accounting prevalent in the UK over the past three decades - the revaluation of property assets and the crediting of that revaluation direct to a reserve account.

Note 2. Note that, the model assumes an economy with risk neutrality and homogenous beliefs, as well as the interest rate satisfying a non-stochastic and flat term structure.

Note 3. The residual income model expresses the market value of equity as current equity book value plus discounted expected residual income to equity holders.

Note 4. Clean surplus accounting implies that all value-relevant information is eventually reflected in the profit and loss account (McCare and Nilsson, 2001).

Note 5. Lo and Lys (2000) argue that the PVED and the RIM are mathematically equivalent. Thus, rejecting the RIM is logically equivalent to rejecting the hypothesis that investors price securities as the present value of all expected future cash flows.

Note 6. Note that as in GST, all estimates are made using a 5\% real cost of capital.

Note 7. For example, see Penman and Sougiannis (1998) for finite-horizon analysis.

Note 8 . Changing this assumption simply requires a revaluation expression for stocks of raw materials and work in progress.

Note 9. Note that in keeping with the usual assumptions of discrete time discounted cash flow models, all cash flows and value changes are assumed to occur at the year end.

Note 10. Following Edwards and Bell (1961) GST partition nominal earnings in any one year into holding gains on assets, debt and real earnings. Assume that asset prices increase in line with general inflation, that net monetary assets (excluding debt), $m_{t}$, are zero (or, equivalently, that the overall average price increase on assets is the rate of inflation), and that the rate of technological improvement is zero. Re-defining book values in terms of current price levels, they have holding gains, $h_{t}$, given by $h_{t}=b_{t-1}^{\prime} \cdot i_{t}$. By assumption there are no real holding gains on assets. As in O'Hanlon and Peasnell (2004) these holding gains can be decomposed into the holding gain on debt, $h_{t}^{d}=D_{t-1} . i_{t}$, and the holding gain on assets, $h_{t}^{a}=A_{t-1} . i_{t}$. As they note, the holding gain on assets is "fictional". However, the gain on debt is not, but merely serves to offset the increased (nominal) interest charge lenders require to offset the decreased purchasing power of the principal. The effect of adjusting for this holding gain on debt is identical (ignoring tax effects) to replacing the nominal interest charge in the profit and loss statement with a real interest charge.

Note 11. Note that 'inflation gain on debt' is not included here, since it is already embedded within the capital maintenance adjustment to opening equity. For example, see O'Hanlon (2005).

Note 12. This is a real terms version of the Edwards and Bell/Peasnell $(1961,1982)$ model, so that accounting is clean surplus in real terms, given the assumption that there are no real holding gains on assets. However, since $-\left(1+r^{\prime}\right)\left(1+i_{t}\right)=-(1+r)$, real abnormal earnings are identical to nominal abnormal earnings based upon current book values. Thus the key distinguishing feature of the GST model is the uplifting of the book values on which the abnormal earnings construct is defined. Once that is done, there is no distinction between "real" and "nominal" abnormal earnings.

Note 13. As in the Ohlson model $\omega$ is assumed to have a value between zero and 1.0. The particular focus of the GST 
model is on the nature of $h_{t}$ within the British accounting system. Here GST partition assets into three categories: property assets, $p$, other fixed assets, $f$, and net working capital, $w$, such that $b_{t}=p_{t}+f_{t}+w_{t}$. They observe that British firms have historically revalued property assets regularly, but that the holding gain is taken directly to reserves in contravention of clean surplus accounting principles. Thus, they make the simplifying assumption that property prices increase in line with general inflation, that no other assets are revalued using "dirty surplus" accounting, and that the working capital holding period is not significantly different from zero days. It then follows that property assets (by virtue of dirty surplus revaluation in line with inflation) and current assets (by assumption) are already valued at current value to the business, but that other fixed assets need to be revalued to reflect the change in price levels. In other words, the adjustments required by (14) and (16) above do not need to be applied to all book assets, but merely to non-property and non-working capital assets.

Note 14. SMB (small minus big) is the difference, each month, between the average of the returns on the three small-stock portfolios $(\mathrm{S} / \mathrm{L}, \mathrm{S} / \mathrm{M}$, and $\mathrm{S} / \mathrm{H})$ and the average of the returns on the three big-stock portfolios $(\mathrm{B} / \mathrm{L}, \mathrm{B} / \mathrm{M}$, and $\mathrm{B} / \mathrm{H})$. HML is the difference, each month, between the average of the returns of the two high-book-to-market portfolios $(\mathrm{S} / \mathrm{H}$ and $\mathrm{B} / \mathrm{H})$ and the average of the returns on the two low-book-to-market portfolios $(\mathrm{S} / \mathrm{L}$ and $\mathrm{B} / \mathrm{L})$. Following Fama and French, and also Gregory, Harris, and Michou (2001), the mimicking portfolios for the size (SMB) and book-to-market (HML) factors are constructed as follows. At the end of June of each year $t$ stocks are allocated to two groups (big or small, b or s) based on whether their market value is above or below the median of the largest 350 companies. Further, stocks are allocated in an independent sort to three book-to-market groups (high, medium, and low; $\mathrm{H}, \mathrm{M}$ or $\mathrm{L}$ ) based on the breakpoints for the top 30 percent, middle 40 percent, and bottom 30 percent of the book-to-market values recorded for the largest 350 companies at the end of year $t-1$. From the intersection of the two size groups ( $\mathrm{S}$ and $\mathrm{B}$ ) and the three book-to-market groups (L, M, H), six size-book-to-market portfolios are constructed (S/L, S/M, S/H, B/L, B/M, B/H). 